4.4. Thời gian phẫu thuật. Thời gian phẫu thuật trung bình của chúng tôi là $163,47 \pm 84,64$ phút, tính thời gian từ lúc cài đặt hệ thống cho đến khi đóng xong da đầu. Thời gian của nhóm nghiên cứu không có sự khác biệt nhiều so với tác giả Paleologos (2000) đó là thời gian phẫu thuật trung bình của nhóm có sử dụng hệ thống định vị là 174 phút, so với nhóm phẫu thuật không sử dung hê thống đinh vị là 204 phút [5].

4.5. Kết quả cải thiện chất lượng sống sau mổ. Điểm Karnofsky của bệnh nhân trước mổ và sau mổ là khác biệt có ý nghĩa thống kê với $p<0,05$. Đa số các bệnh nhân đều cải thiên chất lượng cuộc sống sau mổ tốt hơn so với trước mổ chiếm 87,5\% (Karnofsky thuộc nhóm I, II). Chúng tôi nhận thây rằng ứng dụng hệ thống định vị thần kinh trong phẫu thuật u bán cầu đại não đem lại kết quả tốt cho bệnh nhân.

\section{KẾT LUẬN}

Ứng dụng Neuronavigation trong phẫu thuật u bán câu đại não giúp phẫu thuật viên tự tin cắt bỏ tối đa u não, tăng độ an toàn, bảo tồn vùng chức năng cho kết quả cải thiện chất lượng sống bệnh nhân cao.

\section{TÀI LIÊU THAM KHẢO}

1. Abdullah al-akayleh (2009). Application of neuronavigation in Neurosurgery at King Hussein Medical Center, Jordan.

2. T.Y. Jung et al (2006). Application of Neuronavigation System to Brain Tumor Surger y with Clinical Experience of 420 Cases. Minim Invas Neurosurg 2006; 49: 210-215.

3. R. J. Benveniste, I. M. Germano (2005). Correlation of factors predicting intraoperative brain shift with successful resection of malignant brain tumors using image-guided techniques. Surgical Neurology 63 (2005) 542-549.

4. Gene H. Barnett (1995). Intracranial Meningioma Resection Using Frameless Stereotaxy. Journal of Image Guided Surgery 1:105-52 (1995).

5. Paleologos TS et al (2000). Clinical utility and cost-effectiveness of interactive image-guided craniotomy: Clinical comparison between conventional and image-guided meningioma surgery. Neurosurgery 2000 Jul; 47(1):40-7.

6. Ayhan ONK et al (2003). Treatment of deepseated cerebral lesions by stereotactic craniotomy. Gazi Medical Journal 2003; 14; 23-28.

7. Kiêu Đình Hùng (2010). Ứng dụng navigation (hệ thống định vị) trong phẫu thuật u não tại bệnh viện Đại học Y Hà Nội. Tapp chí Nghiên cứu Y học 2010, phu trương 67 (2), tr $8-12$.

8. Chu Tân Sĩ (2012). Nhận xét kết quả phẫu thuât u não tại Bênh viện nhấn dân 115 . Y học TP. Hồ Chí Minh 2012, tập 16 - số 1.

\title{
MỐI LIÊN QUAN GIŨ̃A THANG ĐIỂM VẬN ĐộNG VÀ TÌNH TRẠNG CHÂ̂M LÀM TRỐNG DẠ DÀY TRONG BỆNH PARKINSON
}

\section{Trần Thanh Hùng*, Vũ Anh Nhị*, Nguyễn Xuân Cảnh**}

\section{TÓM TẮT}

Mở đâu: Bệnh Parkinson là bệnh thoái hóa thần kinh thường gặp đứng hàng thứ hai sau bệnh Alzheimer. Chân đoán chậm làm trống dạ dày có ý nghĩa rất quan trọng trong điều trị bệnh nhân bênh Parkinson. Mục tiêu nghiên cứu: khảo sát mối liên quan giữa thang điểm vận động và tình trạng chậm làm trống dạ dày trong bệnh Parkinson. Phương pháp nghiên cứu: nghiên cứu cắt ngang mô tả, tiến cứu trên bệnh nhân mắc bệnh Parkinson và ký đồng ý tham gia nghiên cứu. Bệnh nhân được đánh giá thang điểm vận động và được thực hiện xạ hình làm trống dạ dày với thức ăn đặc để đánh giá tình trạng chậm làm trống dạ dày. Số liệu được xử lý bằng phần mểm $\mathrm{R}$ phiên bản 4.0.3. Kết quả: Nghiên cứu gồm 72 bênh nhân Parkinson trong đó nữ giới chiếm 73,6\%. Tî̉ lệ

*Đại học Y dược Thành phố Hồ Chí Minh

**Bênh viện Chợ Rẫy

Chịu trách nhiệm chính: Trần Thanh Hùng

Email: tranthanhhungmd@ump.edu.vn

Ngày nhận bài: 2.4.2021

Ngày phản biện khoa học: 21.5.2021

Ngày duyệt bài: 2.6 .2021 chậm làm trống dạ dày trên xạ hình là 45,8\%. Điểm số triệu chứng chậm vận động toàn thân, tăng trương lực cở ngoại tháp, thay đổi tư thế đứng càng cao thì càng có nguy cơ chậm làm trống dạ dày, ngược lại điểm số triệu chứng run tay tứ thế càng cao thì càng ít có nguy cơ chậm làm trống dạ dày, kiểm định Kruskall-Wallis, $p$ tương ứng là: 0,$007 ; 0,041 ; 0,002$; 0,027 . Kết luận: cân nhận biết các kiêuu hình lâm sàng khác nhau của bênh Parkinson, từ đó tiến hành khảo sát tình trang chậm làmm trống dạ dày ở bệnh nhân.

Tì̛ khóa: thang điếm MDS UPDRS phần III, chậm làm trống dạ dày.

\section{SUMMARY \\ CORRELATION BETWEEN MOTOR SCALE AND DELAYED GASTRIC EMPTYING IN PARKINSON DISEASE}

Background: Parkinson's disease (PD) is the second most common neurodegenerative disease after Alzheimer disease. Delayed gastric emptying could be impactful in treatment of PD patients. Objectives: To investigate the correlation between motor scale and delayed gastric emptying in PD. Methods: A crosssectional study was conducted on PD patients with their informed consent. Patients were evaluated on 
their motor complications using UPDRS and were also received radionuclide gastric emptying study using solid meal. The analysis was done using $R$ version 4.0.3. Results: Seventy-two patients were included in our study with $73.6 \%$ were female. There were $72.2 \%$ patients with at least one motor complications. The delayed gastric emptying rate was $45.8 \%$. Patient with delayed gastric emptying had statistically higher score on rigidity, extrapyramidal symptoms, postural instability $(p<0.01)$ and lower score on postural tremor of the hands $(p=0.027)$ compared to patient without delayed gastric emptying using Kruskall-Wallis test. Conclusions: Motor symptoms of Parkinson disease need to be recognized by clinicians to evaluate delayed gastric emptying in PD patients.

Keywords. MDS UPDRS part III, delayed gastric emptying.

\section{I. ĐĂT VẤN ĐỀ}

Bệnh Parkinson là bênh thoái hóa thần kinh thường gặp đứng hàng thứ hai sau bệnh Alzheimer. Chẩn đoán chậm làm trông dạ dày ở bệnh nhân bệnh Parkinson có ý nghĩa rất quan trọng trong thực hành lâm sàng [7]. Những bệnh nhân bệnh Parkinson có chậm làm trống dạ dày với giảm hấp thu levodopa và dao động vận động sẽ được xem xét dùng thuốc làm tăng nhu động dạ dày hoặc sử dụng phương pháp dùng thuốc không qua đường uống. Ở Việt Nam hiện nay, chưa có nghiên cứu nào khảo sát yếu tố tiên lượng tình trạng chậm làm trống dạ dày ở bệnh nhân bệnh Parkinson. Vì vậy chúng tôi tiến hành nghiên cứu này nhằm khảo sát mối liên quan giữa thang điểm vận động và tình trạng chậm làm trống dạ dày trong bệnh Parkinson.
II. ĐỐI TƯỢNG VÀ PHƯƠNG PHÁP NGHIÊN CỨU

Nghiên cứu là một phần kết quả trong nghiên cứu "Các yếu tố tiên lượng chậm làm trống da dày ở bệnh nhân Parkinson" đã được hội đồng y đức Đại học y dược TP. Hồ Chí Minh thông qua.

Đối tượng nghiên cứu: bênh nhân mắc bênh Parkinson được khám và theo dõi định kì tại phòng khám chuyên khoa bệnh Parkinson và các rối loạn vận động, bệnh viện Nguyễn Tri Phương. Bênh nhân được chụ xa hình làm trống dạ dày tại khoa Y Học Hạt Nhân, bệnh viện Chợ Rẫy, thành phố Hồ Chí Minh.

Tiêu chuẩn chọn mẫu: Bênh nhân tuổi $\geq$ 18 được chẩn đoán bệnh Parkinson theo tiêu chuẩn MDS Clinical Diagnostic Criteria for Parkinson's Disease 2015[8], đồng ý tham gia nghiên cứu.

Tiêu chuẩn loai trừ:Tiền căn bênh tắc nghẽn da dày-ruôtt. Tiền căn phẫu thuât da dàyruột (ngoại trừ mổ viêm ruột thừa). Bệnh nhân được nuôi ăn qua đường ruôt. Bênh nhân có bệnh nội khoa nặng, không chờ đợi làm xạ hình được. Bênh nhân đái tháo đường kiểm soát kém. Bệnh nhân dị ứng với trứng. Phụ nữ có khả năng mang thai mà không dùng phương pháp ngừa thai hiệu quả. Phụ nữ mang thai. Phụ nữ đang cho con bú

Phương pháp nghiên cứu:

Thiết kế nghiên cứu: cắt ngang mô tả, tiến cứu

Cõ̃ mẫu: dựa theo công thức tính tỷ lệ trong nghiên cứu cắt ngang

Phương pháp lấy mẫu: lấy mẫu liên tục không xác suất

\section{Sơ đồ thu thập dữ liệu:}

\section{Bước 1: chọn bệnh.}

$\checkmark$ bệnh nhân được khám, chẩn đoán, điều trị và theo dõi tại phòng khám chuyên khoa bệnh Parkinson và các rối loạn vận động bệnh viện Nguyễn Tri Phương

$\checkmark$ bệnh nhân được tư vấn, giải thích về nghiên cứu , bệnh nhân ký đồng ý tham gia nghiên cứu

Bước 2: thu thập các dữ liệu về đặc điểm lâm sàng và điều trị bệnh Parkinson

Bước 3: tại khoa Y học hạt nhân bệnh viện Chợ Rẫy,

đánh giá thang điểm vận động MDS-UPDRS phần III [2]: tại thời điểm 1 giờ sau khi uống thuốc điều trị dopaminergic

$\checkmark$ tiến hành xạ hình dạ dày làm trống dạ dày và ghi nhận kết quả

Phân tích thống kê: Nhập liệu và mã hóa bằng Excel và phân tích số liệu bằng phần mềm $\mathrm{R}$ phiên bản 4.0.3 
Tính bình thường của dữ liệu là biến định lượng được đánh giá trực quan bằng biểu đồ và đánh giá khách quan bằng kiểm định ShapiroWilk normality. Các biến định lượng có phân phối không chuẩn sẽ dùng kiểm định Kruskall-Wallis. Giá trị $p<0,05$ được xem là có ý nghĩa thống kê cho tất cả các phân tích.

\section{KẾT QUẢ NGHIÊN CỨU \\ Đặc điểm chung của mẫu nghiên cứu}

Chúng tôi bắt đầu sàng lọc bệnh nhân để đưa vào nghiên cứu từ tháng 1 năm 2018 và tiến hành thu thập số liệu đến tháng 2 năm 2021. Trong khoảng thời gian nghiên cứu chúng tôi có được 72 bệnh nhân hoàn tất qui trình nghiên cứu. Tuổi trung vị là 65,5 tuổi. Tuổi thấp nhất là 37 và tuổi cao nhất là 92 tuổi. Tuổi khởi phát trung vị là 57 tuổi. Tuổi khởi phát thấp nhất là 21 và tuổi khởi phát cao nhất là 79 tuổi. Giới nữ chiếm đa số, có $53 / 72$ bệnh nhân là nữ giới, chiếm 73,6\%.

\section{Bảng Đặc điểm độ tuổi, thời gian bênh.}

\begin{tabular}{|c|c|}
\hline Đặc điểm & $\begin{array}{c}\text { Giá trị (trung vị và } \\
\text { khoảng tứ phân vị) }\end{array}$ \\
\hline Tuổi (năm) & $65,5[57,0 ; 71,0]$ \\
\hline Tuổi khởi phát (năm) & $57,0[51,0 ; 65,0]$ \\
\hline Thời gian bệnh(năm) & $6,00[3,00 ; 10,0]$ \\
\hline
\end{tabular}

Đặc điểm thang điểm vận động của mầu nghiển cứu: Tổng điểm số trung vị MDS-UPDRS phần III là 40,5 $[28,0 ; 50,0] / 132$. Kết quả nghiên cứu cho thây run là nhóm triệu chứng nhẹ nhất với khoảng tứ phân vị dao đồng từ 0 đến 1 . Kế đến là nhóm triệu chứng tăng trương lực cơ ngoại tháp với khoảng tứ phân vị dao động từ 0 đến 2. Nhóm triệu chứng chậm vận động /bất động là nặng nhất với khoảng tứ phân vị dao động từ 1 đến 3 . Điều này cho thấy phần lớn bệnh nhân trong nghiên cứu của chúng tôi thuộc kiểu hình bệnh Parkinson với tăng trương lực cơ ngoại tháp, chậm vận động là ưu thế, kế đến là kiểu hình rối loạn tư thế đứng và dáng đi. Kiểu hình bệnh Parkinson với triệu chứng run ưu thế thì ít gặp hơn. Trong nhóm triêu chứng run thì triệu chứng run khi duy trì tư thế và khi vận động thì thường gặp hơn là triệu chứng run khi nghỉ.

Đặc điểm xạ hình làm trống dạ dày: Phần lớn bệnh nhân trong mẫu nghiên cứu có thời gian làm trống $1 / 2$ dạ dày nằm trong khoảng từ 50 phút đến 75 phút. Thời gian làm trống $1 / 2$ dạ nhanh nhất là: 28 phút. Có hai bệnh nhân có thời gian làm trống da dày kéo dài $>120$ phút. ở một bệnh nhân, ghi nhận chỉ làm trống được $47 \%$ thức ăn trong da dày ở thời điểm 120 phút. Bệnh nhân còn lại chỉ làm trống được $8 \%$ thức ăn trong dạ dày ở thời điểm 120 phút khi khảo sát xạ hình làm trống dạ dày. Dựa trên giá trị ngưỡng bình thường là $\leq 61$ phút [1] [4], trong nghiên cứu của chúng tôi có 33 bệnh nhân, chiếm tỉ lệ 45,8\%, có tình trạng chậm làm trống dạ dày.

Mối liên quan với thang điểm vận động: Bệnh nhân có chậm làm trống dạ dày thì có tổng điểm số MDS UPDRS phần III cao hơn $(44,0$ $[33,0 ; 51,0)]$ so với bệnh nhân không có chậm làm trống dạ dày $(37,0[26,5 ; 47,0])$. Tuy nhiên sự khác biệt không có ý nghĩa thống kê, $p=$ 0,116 . Chúng tôi tiến hành phân tích tìm mối liên quan giữa các đặc điểm của triệu chứng vận động khi đánh giá bằng thang điểm MDS UPDRS phần III với tình trạng chậm làm trống dạ dày. Thang điểm này đánh giá chức năng vận động ở bệnh nhân bệnh Parkinson ở bốn khía cạnh gồm: chậm vận động/bất động, tăng trương lực cơ ngoại tháp, thay đổi tư thế đứng/dáng đi và run. Mối triệu chứng vận động sẽ được cho điểm là: $0,1,2,3,4$. Trong đó 0 điểm là bình thường, 4 điểm là triệu chứng nặng nhất.

Tăng trương lực cơ ngoại tháp chi trên bên phải có liên quan có ý nghĩa thống kê với tình trạng chậm làm trống dạ dày. Bệnh nhân có chậm làm trống dạ dày thì có điểm số tăng trương lực cơ ngoại tháp chi trên bên phải cao hơn so với bênh nhân không có chậm làm trống dạ dày kiểm định Kruskall-Wallis, $p=0,041$. Do tăng trương lực cơ ngoại tháp ở chi trên bên phải chỉ là một phần trong đánh giá triệu chứng tăng trương lực cơ ngoại tháp nói chung, nên chúng tôi khi tiến hành gộp các biến số tăng trương lực cơ: vùng cổ, chi trên hai bên, chi dưới hai bên để đưa ra một biến số chung là tăng trương lực cơ ngoại tháp chung. Khi phân tích, chúng tối không tìm thấy mối liên quan có ý nghĩa thống kê giữa triệu chứng tăng trương lực cơ ngoại tháp chung với tình trạng chậm làm trống dạ dày.

Điểm số tư thế đứng có liên quan có ý nghĩa thống kê với tình trạng chậm làm trống dạ dày. Bệnh nhân có chậm làm trống dạ dày thì có điểm số bất thường tư thế đứng cao hơn so với bệnh nhân không có chậm làm trống dạ dày kiểm định Kruskall-Wallis, $p=0,002$.

Chậm vận động toàn thân có liên quan có ý nghĩa thống kê với tình trạng chậm làm trống dạ dày. Bệnh nhân có chậm làm trống dạ dày thì có điểm số chậm vận động toàn thân cao hơn so với bệnh nhân không có chậm làm trống dạ dày kiểm định Kruskall-Wallis, $\mathrm{p}=0,007$. 

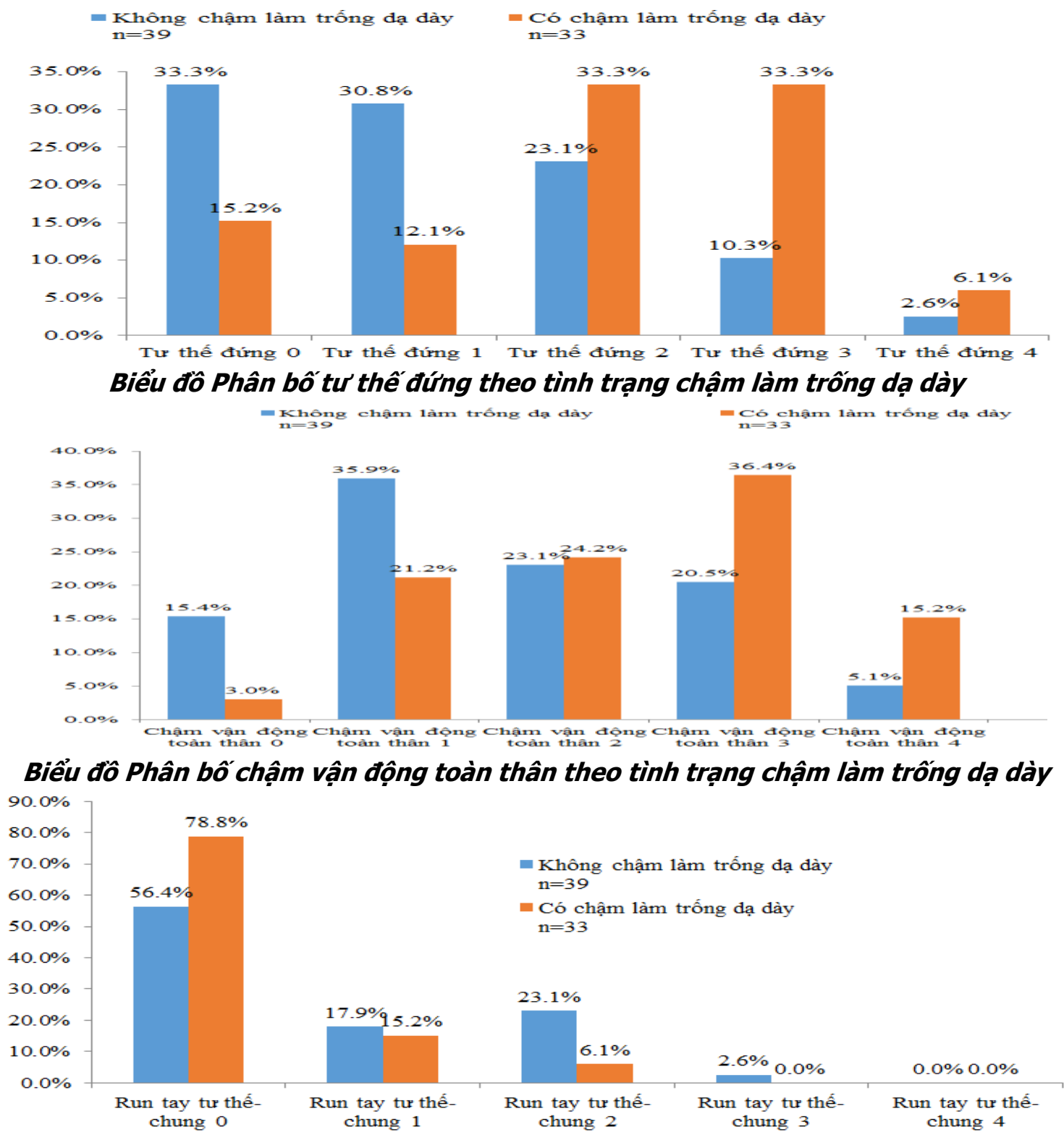

\section{Biểu đồ Phân bố run tay tư thế-chung theo tình trạng chậm làm trông dạ dày}

Run tay tư thế chung có liên quan có ý nghĩa thống kê với tình trạng chậm làm trống dạ dày. Bênh nhân có chậm làm trống dạ dày thì có điểm số run tay tư thế chung thấp hơn so với bệnh nhân không có chậm làm trống dạ dày, kiểm định Kruskall-Wallis, $p=0,027$.

\section{BÀN LUÂ̂N}

Mặc dù tổng điểm số MDS UPDRS phần III không có sự khác biệt có ý nghĩa thống kê giữa hai nhóm bệnh nhân có hay không có chậm làm trống da dày nhưng khi phân tích từng mục của thang điểm vận động chúng tôi tìm thấy các biến số tăng trương lực cơ ngoai tháp, thay đổi tư thế đứng, chậm vận động toàn thân có tương quan thuận với tình trạng chậm làm trống dạ dày. Nhửng bệnh nhân có chậm làm trống da dày thì có điểm số các mục này cao hơn so với những bệnh nhân không có chậm làm giống dạ dày, với mức ý nghĩa thống kê p lần lượt là $0,041,0,002$ và 0,007 . Ngược lại, biến số run tay tư thế tương quan nghịch với tình trạng châm làm trống da dày. Những bệnh nhân có chậm làm trống da dày thì có điểm số run tay tư thế thấp hơn so với những bệnh nhân không có chậm làm giống da dày, với mức ý nghĩa thống kề $p=0,027$. Kết 
quả nghiên cứu của chúng tôi tương tự với kết quả nghiên cứu của các tác giả khác.

Goetze và cs, năm 2006 [3] nghiên cứu xa hình làm trống dạ dày, sử dụng test hơi thở với thức ăn đặc ở 40 bêenh nhân bệnh Parkinson, độ tuổi $63 \pm 11$ tuổi, tuổi khởi phát triệu chứng 56 \pm 11 tuổi, thời gian bệnh trung bình 6,2 $\pm 4,85$ năm. Có 8 bệnh nhẩn (chiếm 20\%) là bệnh Parkinson mới được chẩn đoán, chưa được điều trị. Kết quả test hơi thở được so sánh với nhóm chứng khỏe mạnh bắt cặp theo độ tuổi và giới tính. Nghiên cứu cho thây trong mổ hình hồi quy đa biến, tăng trương lực cơ ngoại tháp có tương quan thuận với tình trạng chậm làm trống dạ dày, $\mathrm{t}=4,47, \mathrm{p}<0,001$. Trong nghiên cứu này các tác giả sử dụng thang điểm UPDRS phần III. Sự khác biệt của thang điểm này với thang điểm MDS UPDRS phần III là ở chố thang điểm UPDRS phần III chỉ cho 1 mục chung cho cả run khi vận động và run khi duy trì tư thế chứ không tách thành 2 mục riêng là run khi vận động và run khi duy trì tư thế như thang điểm MDS UPDRS phần III. Kết quả của nghiên cứu này cho thây run khi vận động/run khi duy trì tư thế có tương quan nghịch với tình trạng chậm làm trống dạ dày, $\mathrm{t}=-2,42, \mathrm{p}<0,05$.

Như vậy kết quả nghiên cứu của chúng tôi cũng như của các tác giả khác cho thây rằng kiểu hình lâm sàng khác nhau của bệnh Parkinson thì sẽ ảnh hưởng khác nhau đến tốc độ làm trống dạ dày. Có các cách phân loại khác nhau về kiểu hình lâm sàng bệnh Parkinson. Tuy nhiên, cách phân loại phổ biển [5] là chia bệnh Parkinson thành 3 kiểu hình gồm: kiểu hình với run ưu thế (tremor-dominant subtype), kiểu hình chậm vận động/tăng trương lực cơ ngoại tháp (akinetic-rigid subtype) và kiểu hình rối loạn tư thế đứng và dáng đi (postural instability gait disorder subtype: PIGD). Nghiên cứu về bệnh học thần kinh [6] cho thấy khi so sánh giữa kiểu hình chậm vận động/tăng trương lực cơ ngoại tháp với kiểu hình với run ưu thế thì kiểu hình chậm vận động/tăng trương lực cơ ngoại tháp có tổn thương mất tế bào thân kinh ở nhân xanh (locus ceruleus), chất đen nhiều hơn và có tăng sinh tế bào đệm, tích tụ melanin ngoài tế bào thần kinh, loạn dưỡng sợi trục thần kinh ở chất đen nhiêu hớn. Các nghiên cứu dấu ấn sinh học cho thấy bệnh Parkinson kiểu hình không phải run ưu thế thì có tổn thương thoái hóa thần kinh nặng hơn và lan rộng hơn so với kiểu hình bệnh Parkinson với run ưu thế. Tổn thương nặng hơn ảnh hưởng cả con đường dopaminergic và ngoài dopaminergic, cả bệnh học sinh synuclein và ngoài synuclein (Abeta). Điều này phù hợp với đặc điểm lâm sàng các triệu chứng thần kinh thực vật sẽ ảnh hưởng nhiều hơn và sớm trong bệnh Parkinson không phải kiểu hình run ưu thế (kiểu hình chậm vận động/tăng trương lực cơ ngoại tháp và kiểu hình rối loạn tư thế đứng và dáng đi) so với bệnh Parkinson kiểu hình run ưu thế.

Như vậy các kết quả nghiên cứu cho thấy bệnh Parkinson với kiểu hình run ưu thế thì có mức độ tổn thương thần kinh thực vật nhe so với kiểu hình không có run ưu thế (kiểu hình châm vận động/tăng trương lực cơ ngoại tháp và kiểu hình rối loạn tư thế đứng và dáng đi). Điều này giải thích kết quả nghiên cứu của chúng tôi và của tác giả Goetze cho [3] thây điểm số triệu chứng chậm vận động toàn thân, tăng trương lực cơ ngoại tháp, thay đổi tư thế đứng càng cao thì càng có nguy cơ chậm làm trống dạ dày. Ngược lại điểm số triệu chứng run tay tư thế càng cao thì càng ít có nguy cơ chậm làm trống dạ dày.

\section{KẾT LUẬN}

Nghiên cứu chúng tôi cho thây các kiểu hình lâm sàng khác nhau của bệnh Parkinson có liên quan có ý nghĩa thống kê với tình trạng chậm làm trống dạ dày. Điều này nhấn mạnh đến tẩm quan trọng của việc nhận biết các kiểu hình này, từ đó tiến hành khảo sát tình trạng chậm làm trống dạ dày để đánh giá hiệu quả điều trị thuốc uống ở bệnh nhân Parkinson.

\section{TÀI LIÊU THAM KHẢO}

1. Djaildetti, R., Baron, J., Ziv, I. et al (1996), "Gastric emptying in Parkinson's disease: patients with and without response fluctuations", Neurology, 46(4), pp. 1051-1054.

2. Goetz, C. G. et al. (2007). Movement Disorder Society-sponsored revision of the Unified Parkinson's Disease Rating Scale (MDS-UPDRS): process, format, and clinimetric testing plan. Mov. Disord. 22, pp. 41-47

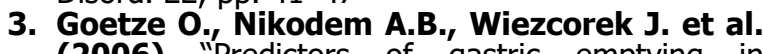
(2006) "Predictors of gastric emptying in Parkinson's disease", Neurogastroenterol Motil, 18(5), pp. 69-375.

4. Hardoff, R., Sula, M., Tamir, A. et al. (2001) "Gastric emptying time and gastric motility in patients with Parkinson's disease", Mov Disord, 16(6), pp. 1041-1047.

5. Marras, C., Chaudhuri, K. R. (2016). Nonmotor features of Parkinson's disease subtypes. Mov. Disord. 31, pp. 1095-1102.

6. Paulus, W, Jellinger, K. (1991). The neuropathologic basis of different clinical subgroups of Parkinson's disease. J. Neuropathol. Exp. Neurol., 50, pp. 743-755

7. Pfeiffer, R.F. (2018). Gastrointestinal Dysfunction in Parkinson's Disease. Curr Treat Options Neurol. 25;20(12):54. 